\title{
PENGARUH BAURAN PEMASARAN DALAM BISNIS INDUSTRI BATIK TERHADAP KEPUASAN DAN LOYALITAS KONSUMEN PADA PT. BANGSAWAN INDONESIA TEKSTIL GRESIK
}

\author{
Ariefah Sundari ${ }^{1}$, Ana Fitriyatul Bilgies ${ }^{2}$, Ahmad Fathur Rozi ${ }^{3}$ \\ Universitas Islam Darul 'Ulum Lamongan \\ E-mail: ariefah.sundari@unisda.ac.id
}

\begin{abstract}
This study aims to knowing the influence of marketing mix in Bali convection business on cunsomer satisfaction and loyalty in PT. Bangsawan Indonesia Tekstil. This study is explanatory research. Population is all all employees CSR of PT. Petro Kimia Gresik who ordered work uniforms in outlet PT. Bangsawan Tekstil Indonesia. The sampling method for this study was doing with accidental sampling technique and it got 125 respondents. Data analysis method is Structural Equation Modelling (SEM). The results of research are marketing mix which included product, price, place, and promotion have affected significantly towards customer's satisfaction. It indicated that selling product same as customer's needs and wants, the giving price is reached by consumers, location of buying product is strategic, and promotion same as consumer's hope. Marketing mix which included product, price, place, and promotion have not affected significantly towards customer's loyalty. It indicated that the selling product, the giving price, strategic location, and completed promotion could not change consumer to become loyalty at PT. Bangsawan Tekstil Indonesia. Customer's satisfaction have affected significantly towards customer's loyalty. It indicated that loyal customer is always feels satisfy with anything they received.
\end{abstract}

Keywords: Marketing mix, Customer's Satisfaction, Customer's Loyalty.

\begin{abstract}
ABSTRAK
Penelitian ini bertujuan untuk mengetahui pengaruh bauran pemasaran dalam bisnis Batik "Batik Bangsawan" terhadap kepuasan dan loyalitas konsumen pada PT. Bangsawan Indonesia Tekstil. Jenis penelitian adalah explanatory research. Populasi penelitian adalah seluruh karyawan CSR PT. Petro Kimia Gresik yang memesan seragam kerja di PT. Bangsawan Tekstil Indonesia. Metode pengambilan sampel dalam penelitian ini dilakukan dengan teknik accidental sampling dan didapatkan jumlah sampel 125 responden. Metode analisis data yang digunakan adalah analisis SEM (Structural Equation Modelling). Hasil penelitian ini adalah bauran pemasaran yang meliputi produk, harga, tempat, dan promosi berpengaruh signifikan terhadap kepuasan konsumen. Hal ini menunjukkan bahwa produk yang dijual sesuai dengan kebutuhan dan keinginan konsumen, harga yang ditawarkan terjangkau oleh konsumen, lokasi
\end{abstract}


tempat pembelian produk sudah strategis, dan kegiatan promosi sudah sesuai dengan harapan konsumen. Bauran pemasaran yang meliputi produk, harga, tempat, dan promosi berpengaruh tidak signifikan terhadap loyalitas konsumen. Hal ini menunjukkan bahwa produk yang dijual, harga yang ditawarkan, tempat yang strategis, dan promosi yang sudah dilakukan tidak dapat menjadikan konsumen loyal pada PT. Bangsawan Tekstil Indonesia. Kepuasan konsumen berpengaruh signifikan terhadap loyalitas konsumen. Hal ini menunjukkan bahwa konsumen yang loyal dapat dipastikan merasa puas dengan apa yang didapatkannya.

Kata Kunci: Bauran Pemasaran, Kepuasan Konsumen, Loyalitas Konsumen.

\section{PENDAHULUAN}

Pada era saat ini perkembangan dunia fashion batik atau model pakaian sangat cepat berubah dan berkembang pesat. Bukan hanya di Eropa tetapi masyarakat di Indonesia juga sangat mengikuti perkembangan fashion atau model baju yang sedang trend di dunia. Ini menimbulkan banyak pengusaha- pengusaha yang bergerak dan bertahan di produksi tekstil batik. Banyak perusahaan tekstil batik yang memberikan suatu keunikan dalam produksinya agar mempunyai daya saing dan beda dengan yang lainnya. kebanyakan suatu perusahaan serta kantor kedinasan mewajibkan baju kerjanyanya menggunakan batik dihari hari tertentu merupakan suatu sasaran bagi para produsen baik perusahaan maupun usaha menengah kecil (UKM) untuk melakukan pemasaran.

Setiap daerah selalu memiliki ciri khasnya sendiri dalam desain batik sesuai dengan daerah mereka masing- masing. Di setiap daerah pasti memiliki perusahan industri tekstil batik masing-masing. Melihat fenomena tersebut para pelaku bisnis tekstil tentu harus menerapkan strategi pemasaran yang menarik serta terus melakukan inovasi agar dapat bertahan dan berkembang, dengan kata lain, industri tekstil batik yang sudah berjalan maupun pendatang baru, seakan terus dituntut untuk memberikan penawaran- penawaran yang paling menguntungkan bagi konsumen dalam programprogram pemasarannya untuk dapat memenangkan persaingan.

Bisnis Tekstil Batik adalah salah satu jenis bisnis yang cukup populer di Indonesia. Tersebar hampir di setiap daerah. Kepopuleran bisnis tekstil Batik utamanya adalah disebabkan karena dua hal. Pertama, karena produk yang dihasilkan oleh industri tekstil batik, yaitu pakaian merupakan salah satu kebutuhan dasar manusia, maka 
market untuk bisnis industry tekstil batik akan selalu ada. Pangsa pasar yang jelas, membuat tidak sedikit orang yang berusaha memaksimalkan potensi dari bisnis konveksi.

Bisnis Industri tekstil batik menjadi populer karena entry barrier untuk bisa memulai bisnis ini tidak terlalu besar. Seseorang bisa memulai sebuah bisnis industry tekstil batik dengan hanya bermodalkan dua atau tiga buah Canting sebagai alat pembentuk motif, Gawangan (tempat untuk menyampirkan kain), Lilin (malam) yang dicairkan, Panci dan kompor kecil untuk memanaskan, Larutan pewarna. Merupakan alat produksi termurah. Tidak seperti mesin-mesin produksi di industri lainnya yang harganya bisa mencapai ratusan juta atau bahkan milyaran rupiah, seseorang bisa membeli peralatan ini hanya dengan harga ratusan ribu rupiah saja. Seseorang bisa memulai berbisnis industry tekstil batik dari garasi rumhanya yang luasnya hanya beberapa meter persegi saja, tidak perlu membuat pabrik yang luasnya ratusan atau ribuan meter persegi.

Salah satu perusahaan Industri tekstil batik yang terkenal di Gresik adalah PT. Bangsawan Tekstil Indonesia. Perusahaan ini bertempat di di Desa Sungon Legowo, Kecamatan Bungah, Kabupaten Gresik, dengan kualitas produksinya yang sangat optimal membuat PT. Bangsawan Tekstil Indonesia yang di miliki oleh Bapak Nur Cholis $\mathrm{SH}$, ini dapat memproduksi hasil batik dengan motif-motif bercirikan nafas kehidupan Gresik. yang bernama "kawulo alit" yang mengangkat 60 lebih fragmen masyarakat pesisir Gresik yang mampu bersaing di pasar domestik. Perusahaan ini mempunyai keunggulan dan memiliki identitas atau ciri khas sendiri di tahap proses mengatur kekentalan lilin dan kepekatan warna, penambahan bahan lain yang tidak masuk komposisi, intensitas matahari dan kandungan garam, Cating dan desain yang memadukan unsur lokal budaya dan unsur modern. Kelebihan dari produk ini adalah memiliki tema atau karakter dari desain yang sangat kuat, desain dari produknya mengambil tema kehidupan masyarakat gresik. Kualitas yang bagus dan pelayanan yang ramah membuat kepuasan sendiri terhadap konsumen dan konsumen dapat loyal terhadap perusahaan ini. PT. Bangsawan Tekstil Indonesia dan juga memiliki outlet, namun sekarang mulai mengembangkan pemasaran untuk pasar menengah ke atas yang dijangkau melalui kegiatan direct selling ke perusahaan dan penjualan online di website, 
Facebook, Instagram dan market place, ini juga memudahkan para konsumen untuk berbelanja.

Berdasarkan latar belakang yang telah diuraikan diatas, maka rumusan masalah dari penelitian ini adalah

1. Apakah variabel produk, harga, tempat, dan promosi berpengaruh terhadap kepuasan konsumen PT. Bangsawan Tekstil Indonesia?

2. Apakah variabel produk, harga, tempat, dan promosi berpengaruh terhadap loyalitas konsumen PT. Bangsawan Tekstil Indonesia

3. Apakah kepuasan konsumen berpengaruh terhadap loyalitas konsumen PT. Bangsawan Tekstil Indonesia?

Penelitian ini bertujuan untuk mengetahui pengaruh bauran pemasaran dalam bisnis Industri Tekstil Batik di Gresik terhadap kepuasan dan loyalitas konsumen pada PT. Bangsawan Tekstil Indonesia.

\section{LANDASAN TEORI}

Bauran Pemasaran atau Marketing Mix merupakan kumpulan dari variabelvariabel pemasaran yang dapat dikendalikan yang digunakan oleh suatu badan usaha untuk mencapai tujuan pemasaran dalam pasar sasaran. menurut Philip Kotler (2005:17), bauran pemasaran atau marketing mix adalah perangkat alat pemasaran taktis yang dapat dikendalikan, produk, harga, distribusi, dan promosi yang dipadukan oleh perusahaan untuk menghasilkan respons yang diinginkan dalam pasar sasaran. Berdasarkan para ahli marketing berpendapat, Marketing mix adalah strategi mengkombinasikan kegiatan-kegiatan marketing, agar tercipta kombinasi maksimal sehingga memunculkan hasil paling memuaskan (Alma, 2018:205).

Kepuasan konsumen adalah tingkat perasaan konsumen setelah membandingkan antara apa yang dia terima dan harapannya (Husein Umar, 2014:65). Seorang pelanggan, jika merasa puas dengan nilai yang diberikan oleh produk atau jasa, sangat besar kemungkinannya menjadi pelanggan dalam waktu yang lama.Memuaskan kebutuhan konsumen adalah keinginan setiap perusahaan. Selain faktor penting bagi kelangsungan hidup perusahaan, memuaskan kebutuhan konsumen dapat meningkatkan keunggulan dalam persaingan. Konsumen yang puas terhadap produk dan jasa 
pelayanan cenderung untuk membeli kembali produk dan menggunakan kembali jasa pada saat kebutuhan yang sama muncul kembali dikemudian hari. Hal ini berarti kepuasan merupakan faktor kunci bagi konsumen dalam melakukan pembelian ulang yang merupakan porsi terbesar dari volume penjualan perusahaan.

Loyalitas pelanggan sangat penting artinya bagi perusahaan yang menjaga kelangsungan usahanya maupun kelangsungan kegiatan usahanya. Pelanggan yang setia adalah mereka yang sangat puas dengan produk dan pelayanan tertentu, sehingga mempunyai antusiasme untuk memperkenalkannya kepada siapapun yang mereka kenal. Selanjutnya pada tahap berikutnya pelanggan yang loyal tersebut akan memperluas "kesetiaan" mereka pada produk-produk lain buatan produsen yang sama. Dan pada akhirnya mereka adalah konsumen yang setia pada produsen atau perusahaan tertentu untuk selamanya. Kotler dan Keller (2007:25) menyatakan bahwa loyalitas tinggi adalah pelanggan yang melakukan pembelian dengan prosentasi makin meningkat pada perusahaan tertentu dari perusahaan lain. Dalam penelitian menunjukan terdapat pengaruh positif dan signifikan antara variabel di bauran pemasaran terhadap loyalitas konsumen. Persaingan dalam bisnis pakaian oleh- oleh ini bergerak sangat cepat. Kondisi tersebut berhadapan pula dengan industri sejenis dengan tingkat persaingan yang semakin tajam di pasar domestik, masing-masing industri konveksi berlomba untuk menarik pelanggan dengan mengoptimalkan kualitas produk. karena apabila perusahaan ingin memenangkan persaingan bisnis harus memberikan nilai yang terbaik bagi para pelanggannya. Hal ini juga mendorong terciptanya sebuah strategi bersaing yang tepat agar perusahaan mampu bersaing di tengah-tengah gejolak pasar seperti saat ini.

\section{METODE PENELITIAN}

Rancangan penelitian ini merupakan penelitian penjelasan (explanatory research). Jenis data dalam penelitian adalah data kuantitatif yang diperoleh melalui penyebaran kuisoner pada konsumen yang membeli kain Batik di Outlet PT. Bangsawan Tekstil Indonesia (Karyawan CSR PT. Petrokimia Gresik). Populasi penelitian ini adalah seluruh seluruh Karyawan CSR PT. Petrokimia Gresik yang membeli produk Kain Batik di outlet Batik Bangsawan. Metode pengambilan sampel 
di lakukan dengan cara Accidental Sampling dengan jumlah sampel ditetapkan sebesar 125 responden. Penelitian ini menggunakan metode analisis SEM (Structural Equation Modelling).

\section{HASIL DAN PEMBAHASAN}

Karakteristik Responden

Tabel 1. Karakteristik Responden Berdasarkan Jenis Kelamin

\begin{tabular}{|l|l|l|}
\hline Jenis Kelamin & Frekuensi & Persentase \% \\
\hline Perempuan & 50 & 37,5 \\
\hline Laki-laki & 75 & 62,5 \\
\hline Jumlah & 125 & 100 \\
\hline
\end{tabular}

Berdasarkan Tabel 1, jumlah sampel pada penelitian ini sejumlah 125 responden dan di ketahui bahwa jumlah responden laki-laki lebih banyak daripada responden perempuan yaitu sebanyak 75 responden atau $62.5 \%$ dari total sampel, hal ini dikatakan wajar karena responden laki-laki lebih banyak jumlah karyawan di PT. Petrokimia Gresik. Di lapangan, responden laki-laki lebih antusias dalam mengisi kuesioner dan meminta pendapat mengenai Batik yang di produksi PT. Bangsawan Tekstil Indonesia..

Tabel 2. Karakteristik Responden Berdasarkan Usia

\begin{tabular}{|c|c|c|}
\hline USIA & JUMLAH & PERSENTASE \% \\
\hline $17-25$ th & 15 & 12 \\
\hline $26-35$ th & 57 & 45,6 \\
\hline $36-45$ th & 35 & 28 \\
\hline $46-55$ th & 10 & 8 \\
\hline$>55$ th & 8 & 6,4 \\
\hline
\end{tabular}

Berdasarkan Tabel 2, jumlah sampel pada penelitian ini sejumlah 125 responden, Dengan jumlah responden berusia 26-35 tahun mendominasi dalam hal pembelian produk baju sebanyak 45,6 \% yang menandakan responden berusia 26-35 tahun adalah pelanggan yang paling banyak membeli produk Batik di PT. Bangsawan Tekstil Indonesia. Orang yang berusia 26-35 tahun adalah orang masih memiliki energi 
untuk melakukan banyak hal. Kebanyakan peneliti mendapatkan responden yang berumur 30 tahun.

Analisis SEM (Structural Equation Modelling)

Uji Kesesuaian Model (Goodness of Fit Test)

Tabel 3. Indeks Kesesuaian SEM

\begin{tabular}{|c|c|c|c|}
\hline Kriteria Fit Model & Nilai Fit Model & Standar & Keterangan \\
\hline $\mathrm{X}_{2}$-chi-square & 142.122 & $\begin{array}{c}\text { Diharapkan lebih kecil } \\
\text { dari } \mathrm{X}^{2} \text { pada } \mathrm{df}=125 \\
\text { yaitu } 1533.198\end{array}$ & Baik \\
\hline Significance Probability & 0.000 & $\geq 0.05$ & Marginal \\
\hline RMSEA & 0.196 & $\leq 0.08$ & Marginal \\
\hline GFI & 0.901 & $\geq 0.90$ & Baik \\
\hline AGFI & 0.916 & $\geq 0.90$ & Baik \\
\hline CMIN/DF & 1.797 & $\leq 2$ atau 3 & Baik \\
\hline TLI & 0,976 & $\geq 0.90$ & Baik \\
\hline CFI & 0.969 & $\geq 0.90$ & Baik \\
\hline
\end{tabular}

Tabel 3, diketahui bahwa dari delapan kriteria yang digunakan untuk menilai baik atau layak tidaknya suatu model ternyata empat kriteria terpenuhi dan empat kriteria marginal. Dengan demikian dapat dikatakan model dapat diterima, yang berarti ada kesesuaian antara model dengan data.

\section{Uji Kausalitas}

Tabel 4. Hasil Pengujian Kausalitas

\begin{tabular}{|c|c|c|c|c|}
\hline Hipotesis & Koefisien Jalur & CR & Probabilitas & Keterangan \\
\hline $\mathrm{Y} 1 \leftarrow \mathrm{X} 1$ & 0.219 & 2.340 & 0.019 & Signifikan \\
\hline $\mathrm{Y} 1 \leftarrow \mathrm{X} 2$ & 0.195 & 1.985 & 0.043 & Signifikan \\
\hline $\mathrm{Y} 1 \leftarrow \mathrm{X} 3$ & 0.411 & 2.175 & 0.030 & Signifikan \\
\hline $\mathrm{Y} 1 \leftarrow \mathrm{X} 4$ & 0.533 & 4.189 & 0.000 & Signifikan \\
\hline $\mathrm{Y} 2 \leftarrow \mathrm{X} 1$ & -0.186 & -1.088 & 0.277 & Tidak Signifikan \\
\hline $\mathrm{Y} 2 \leftarrow \mathrm{X} 2$ & -0.456 & -1.413 & 0.158 & Tidak Signifikan \\
\hline $\mathrm{Y} 2 \leftarrow \mathrm{X} 3$ & -0.456 & -1.413 & 0.158 & Tidak Signifikan \\
\hline $\mathrm{Y} 2 \leftarrow \mathrm{X} 4$ & -0.514 & -1.345 & 0.179 & Tidak Signifikan \\
\hline $\mathrm{Y} 2 \leftarrow \mathrm{Y} 1$ & 1.376 & 2.045 & 0.041 & Signifikan \\
\hline
\end{tabular}

Berdasarkan Tabel 4 dapat diketahui hasil pengujian kausalitas untuk pengaruh variabel produk terhadap kepuasan konsumen memiliki koefisien jalur positif sebesar 
0.219 dengan C.R sebesar 2.340 dan probabilitas (p) dengan tingkat signifikan 0.05 yaitu sebesar 0.019 yang berarti bahwa produk berpengaruh signifikan terhadap kepuasan konsumen Batik Bangsawan. Dengan demikian hipotesis yang menyatakan bahwa variabel produk berpengaruh terhadap kepuasan konsumen terbukti kebenarannya.

Hasil pengujian kausalitas untuk pengaruh variabel harga terhadap kepuasan konsumen memiliki koefisien jalur positif sebesar 0.195 dengan C.R sebesar 1.985 dan probabilitas (p) dengan tingkat signifikan 0.05 yaitu sebesar 0.043 yang berarti bahwa harga berpengaruh signifikan terhadap kepuasan konsumen Batik Bangsawan. Dengan demikian hipotesis yang menyatakan bahwa variabel harga berpengaruh terhadap kepuasan konsumen terbukti kebenarannya.

Hasil pengujian kausalitas untuk pengaruh variabel promosi terhadap kepuasan konsumen memiliki koefisien jalur positif sebesar 0.533 dengan C.R sebesar 4.189 dan probabilitas (p) dengan tingkat signifikan 0.05 yaitu *** atau standar deviasi mendekati nol yang berarti bahwa promosi berpengaruh signifikan terhadap kepuasan konsumen Batik Bangsawani. Dengan demikian hipotesis yang menyatakan bahwa variabel promosi berpengaruh terhadap kepuasan konsumen terbukti kebenarannya.

Hasil pengujian kausalitas untuk pengaruh variabel produk terhadap loyalitas konsumen memiliki koefisien jalur negatif sebesar -0.186 dengan C.R sebesar -1.088 dan probabilitas (p) dengan tingkat signifikan 0.05 yaitu $0.277(>0.05)$ yang berarti bahwa produk tidak berpengaruh signifikan terhadap loyalitas konsumen Batik Bangsawan. Dengan demikian hipotesis yang menyatakan bahwa variabel produk berpengaruh terhadap loyalitas konsumen tidak terbukti kebenarannya.

Hasil pengujian kausalitas untuk pengaruh variabel harga terhadap loyalitas konsumen memiliki koefisien jalur negatif sebesar -0.456 dengan C.R sebesar -1.413 dan probabilitas (p) dengan tingkat signifikan 0.05 yaitu 0.158 (>0.05) yang berarti bahwa harga berpengaruh tidak signifikan terhadap loyalitas konsumen Batik Bangsawan. Dengan demikian hipotesis yang menyatakan bahwa variabel harga berpengaruh terhadap loyalitas konsumen tidak terbukti kebenarannya. 
Hasil pengujian kausalitas untuk pengaruh variabel tempat terhadap loyalitas konsumen memiliki koefisien jalur negatif sebesar -0.215 dengan C.R sebesar -1.287 dan probabilitas (p) dengan tingkat signifikan 0.05 yaitu $0.198(>0.05)$ yang berarti bahwa tempat berpengaruh tidak signifikan terhadap loyalitas konsumen Batik Bangsawan. Dengan demikian hipotesis yang menyatakan bahwa variabel tempat berpengaruh terhadap loyalitas konsumen tidak terbukti kebenarannya. Hasil pengujian kausalitas untuk pengaruh variabel promosi terhadap loyalitas konsumen memiliki koefisien jalur negatif sebesar -0.514 dengan C.R sebesar -1.345 dan probabilitas (p) dengan tingkat signifikan 0.05 yaitu 0.179 (>0.05) yang berarti bahwa promosi berpengaruh tidak signifikan terhadap loyalitas konsumen Batik Bangsawan. Dengan demikian hipotesis yang menyatakan bahwa variabel promosi berpengaruh terhadap loyalitas konsumen tidak terbukti kebenarannya.

Hasil pengujian kausalitas untuk pengaruh variabel kepuasan konsumen terhadap loyalitas konsumen memiliki koefisien jalur positif sebesar 1.376 dengan C.R sebesar 2.045 dan probabilitas (p) dengan tingkat signifikan 0.05 yaitu sebesar

0.041 yang berarti bahwa kepuasan konsumen berpengaruh signifikan terhadap loyaltas konsumen Batik Bangsawan. Dengan demikian hipotesis yang menyatakan bahwa variabel kepuasan konsumen berpengaruh terhadap loyalitas konsumen terbukti kebenarannya.

\section{Pengaruh Produk Terhadap Kepuasan Konsumen PT. Bangsawan Tekstil Indonesia}

Hasil penelitian menunjukkan bahwa variabel produk $\left(\mathrm{X}_{1}\right)$ yang di ukur dengan tiga indikator yaitu kualitas produk, daya tahan produk, dan desain produk dapat di diterima oleh responden pelanggan Batik Bangsawan mempunyai pengaruh positif dan signifikan terhadap kepuasan konsumen Batik Bangsawan. Sehingga hipotesis yang menyatakan bahwa produk berpengaruh signifikan terhadap kepuasan konsumen Batik Bangsawan dapat diterima. Hal ini berarti produk yang di jual atau yang di pasarkan kepada konsumen sudah baik dan menjadi alasan bahwa konsumen Batik Bangsawan merasa puas terhadap produk batik dari perusahaan.

Hasil penelitian ini sependapat dengan teori Handoko (2015:23) Produk dan 
kualitas produk adalah faktor penentu kepuasan konsumen setelah melakukan pembelian dan pemakaian terhadap suatu produk. Dengan kualitas produk yang baik maka keinginan dan kebutuhan konsumen terhadap suatu produk akan terpenuhi, penelitian ini sesuai dengan teori Kotler \& Armstrong (2008:346) bahwa produk merupakan segala sesuatu yang dapat ditawarkan kepasar untuk mendapatkan perhatian, dibeli, digunakan, atau dikonsumsi yang dapat memuaskan keinginan atau kebutuhan.

\section{Pengaruh Harga Terhadap Kepuasan Konsumen PT. Bangsawan Tekstil Indonesia}

Variabel harga $\left(\mathrm{X}_{2}\right)$ yang di ukur dengan tiga indikator yaitu keterjangkauan harga, kesesuaian harga, dan daya saing harga dapat di diterima oleh responden pelanggan Batik Bangsawan mempunyai pengaruh positif dan signifikan terhadap kepuasan konsumen. Sehingga hipotesis yang menyatakan bahwa harga berpengaruh signifikan terhadap kepuasan konsumen Batik Bangsawan dapat diterima.

Penelitian ini menjelaskan bahwa harga berpengaruh signifikan terhadap kepuasan konsumen karena berpotensi mempengaruhi persepsi dan harapan konsumen tentang barang atau jasa yang ditawarkan serta pada akhirnya akan mempengaruhi kepuasan konsumen.

\section{Pengaruh Tempat Terhadap Kepuasan Konsumen PT. Bangsawan Tekstil Indonesia}

Variabel tempat $\left(\mathrm{X}_{3}\right)$ yang di ukur dengan tiga indikator yaitu kelancaran akses, jangkauan lokasi, lokasi strategis dapat di diterima oleh responden pelanggan Batik Bangsawan mempunyai pengaruh positif dan signifikan terhadap kepuasan konsumen Batik Bangsawan. Sehingga hipotesis yang menyatakan bahwa tempat berpengaruh signifikan terhadap kepuasan konsumen Batik Bangsawan dapat diterima. Hal ini berarti tempat dimana konsumen membeli produk Batik Bangsawan sudah baik dan menjadi alasan bahwa konsumen Batik Bangsawan merasa puas terhadap tempat penjualan di outlet Batik Bangsawan. Hasil Penelitian ini membuktikan bahwa tempat memiliki pengaruh terhadap kepuasan konsumen dengan akses tempat yang terjangkau maka keinginan konsumen untuk datang akan bertambah. 


\section{Pengaruh Promosi Terhadap Kepuasan Konsumen PT. Bangsawan Tekstil Indonesia}

Variabel promosi $\left(\mathrm{X}_{4}\right)$ yang di ukur dengan tiga indikator yaitu personal selling, advertising, dan public reaction dapat di diterima oleh responden pelanggan Batik Bangsawan mempunyai pengaruh positif dan signifikan terhadap kepuasan konsumen Batik Bangsawan. Sehingga hipotesis yang menyatakan bahwa promosi berpengaruh signifikan terhadap kepuasan konsumen Batik Bangsawan dapat diterima. Hal ini berarti promosi dimana konsumen mendapatkan informasi tentang produk dari Batik Bangsawan sudah baik dan menjadi alasan bahwa konsumen merasa puas terhadap promosi dari Batik Bangswan. Hasil Penelitian membuktikan bahwa promosi memiliki pengaruh terhadap kepuasan konsumen. Promosi merupakan strategi perusahaan yang penting untuk meningkatkan tingkat penjualan dan perusahaan produk Batik Bangsawan. Dengan melakukan promosi maka minat konsumen untuk berbelanja dan datang ke outlet akan bertambah.

\section{Pengaruh Produk Terhadap Loyalitas Konsumen PT. Bangsawan Tekstil Indonesia}

Hasil penelitian menunjukkan bahwa variabel produk $\left(\mathrm{X}_{1}\right)$ yang di ukur dengan tiga indikator yaitu kualitas produk, daya tahan produk, dan desain produk dapat di diterima oleh responden pelanggan Batik Bangsawan mempunyai pengaruh positif namun tidak signifikan terhadap loyalitas konsumen. Sehingga hipotesis yang menyatakan bahwa produk berpengaruh signifikan terhadap kepuasan konsumen Batik Bangsawan tidak dapat diterima. Berdasarkan penelitian ini membuktikan bahwa produk memiliki pengaruh terhadap loyalitas konsumen pada Batik Bangsawan karena berpotensi mempengaruhi persepsi dan harapan konsumen tentang barang atau jasa yang ditawarkan serta pada akhirnya akan mempengaruhi loyalitas konsumen. Tetapi hal ini tidak berlaku kepada konsumen Batik Bangsawan karena beberapa konsumen masih merasakan produk baju dari Batik Bangsawan tidak sesuai dengan selera konsumen. Jadi konsumen tidak mau membeli kembali atau hanya puas sesaat dan tidak ingin loyal terhadap Batik Bangsawan . 


\section{Pengaruh Harga Terhadap Loyalitas Konsumen PT. Bangsawan Tekstil Indonesia}

Hasil penelitian menunjukkan bahwa variabel harga $\left(\mathrm{X}_{2}\right)$ yang di ukur dengan tiga indikator yaitu keterjangkauan harga, kesesuaian harga, dan daya saing harga dapat di diterima oleh responden pelanggan Batik Bangsawan mempunyai pengaruh positif namun tidak signifikan terhadap loyalitas konsumen. Sehingga hipotesis yang menyatakan bahwa harga berpengaruh signifikan terhadap loyalitas konsumen Batik tidak dapat diterima. hal ini tidak berlaku kepada konsumen Batik Bangsawan karena beberapa konsumen masih merasakan harga dari produk kain Batik Bangsawan tidak sesuai dengan harapan dan keinginan konsumen. Jadi konsumen tidak mau membeli kembali atau hanya puas sesaat dan tidak ingin loyal terhadap produk Batik Bangsawan.

\section{Pengaruh Tempat Terhadap Loyalitas Konsumen PT. Bangsawan Tekstil Indonesia}

Hasil penelitian menunjukkan bahwa variabel tempat $\left(\mathrm{X}_{3}\right)$ yang di ukur dengan tiga indikator yaitu kelancaran akses, jangkauan lokasi, lokasi strategis dapat di diterima oleh responden pelanggan Batik Bangsawan mempunyai pengaruh positif namun tidak signifikan terhadap loyalitas konsumen. Sehingga hipotesis yang menyatakan bahwatempat berpengaruh signifikan terhadap loyalitas konsumen Batik Bangsawan tidak dapat diterima. Berdasarkan penelitian ini membuktikan bahwa tempat memiliki pengaruh terhadap loyalitas konsumen hal ini tidak berlaku kepada konsumen Batik Bangsawan karena beberapa konsumen masih merasakan tempat atau outlet dari produk Batik Bangsawan tidak sesuai dengan harapan dan keinginan konsumen. Jadi konsumen masih ragu untuk datang kembali ke Batik Bangsawan.

Hasil penelitian ini menyimpulkan bahwa tempat berpengaruh tidak signifikan terhadap Loyalitas Konsumen pada Batik Bangsawan. Dalam penelitiannya menjelaskan bahwa tempat berpengaruh tidak signifikan terhadap loyalitas konsumen karena tidak lancarnya akses menuju Oultet Batik Bangsawan yang selalu macet pada siang sampai malam hari. 


\section{Pengaruh Promosi Terhadap Loyalitas Konsumen PT. Bangsawan Tekstil Indonesia}

Hasil penelitian menunjukkan bahwa variabel promosi $\left(\mathrm{X}_{4}\right)$ yang di ukur dengan tiga indikator yaitu personal selling, advertising, dan public reaction dapat di diterima oleh responden pelanggan Batik Bangsawan mempunyai pengaruh positif namun tidak signifikan terhadap loyalitas konsumen. Sehingga hipotesis yang menyatakan bahwa promosi berpengaruh signifikan terhadap loyalitas konsumen Batik Bangsawan tidak dapat diterima. hal ini tidak berlaku kepada konsumen Batik Bangsawan karena beberapa konsumen masih merasakan yang dilakukan oleh Batik Bangsawan tidak sesuai dengan harapan dan keinginan konsumen. Jadi konsumen masih ragu terhadap promosi dari Batik Bangsawan.

\section{Pengaruh Kepuasan Konsumen Terhadap Loyalitas Konsumen PT. Bangsawan Tekstil Indonesia}

Hasil penelitian menunjukan bahwa variabel kepuasan konsumen $\left(\mathrm{Y}_{1}\right)$ dapat di terima oleh konsumen mempunyai pengaruh positif dan signifikan terhadap loyalitas konsumen $\left(\mathrm{Y}_{2}\right)$. Sehingga hipotesis yang menyatakan kepuasan konsumen berpengaruh signifikan terhadap loyalitas konsumen dapat diterima. Produk baju yang di pasarkan oleh Batik Bangsawan memiliki kualitas yang baik, dapat dilihat dari sebagian besar responden merasa puas dengan beberapa aspek seperti produk, harga, tempat dan promosi dari perusahaan. Penelitian ini membuktikan bahwa kepuasan konsumen memiliki pengaruh terhadap loyalitas konsumen produk diantaranya kepuasan konsumen akan produk yang di hasilkan perusahaan memberikan dampak yang baik dalam menciptakan konsumen yang loyal terhadap produk khususnya produk Batik di Batik Bangsawan.

\section{KESIMPULAN}

Bauran pemasaran yang meliputi produk, harga, tempat, dan promosi berpengaruh signifikan terhadap kepuasan konsumen. Hal ini menunjukkan bahwa produk yang dijual sesuai dengan kebutuhan dan keinginan konsumen, harga yang ditawarkan terjangkau oleh konsumen, lokasi tempat pembelian produk sudah strategis, 
dan kegiatan promosi sudah sesuai dengan harapan konsumen. Bauran pemasaran yang meliputi produk, harga, tempat, dan promosi berpengaruh tidak signifikan terhadap loyalitas konsumen. Hal ini menunjukkan bahwa produk yang dijual, harga yang ditawarkan, tempat yang strategis, dan promosi yang sudah dilakukan tidak dapat menjadikan konsumen loyal pada PT. Bangsawan Tekstil Indonesia. Kepuasan konsumen berpengaruh signifikan terhadap loyalitas konsumen. Hal ini menunjukkan bahwa konsumen yang loyal dapat dipastikan merasa puas dengan apa yang didapatkannya.

\section{REFERENSI}

Alma, Buchari. 2018. Manajemen Pemasaran dan Pemasaran Jasa. Cetakan 13. Bandung: CV Alfabeta.

Handoko, T. Hani. 2015. Manajemen Personalia dan Sumber Daya Manusia. Edisi 2. Yogyakarta : BPFE.

Husein, Umar. 2014. Metode Penelitian Metode Penelitian Untuk Skripsi dan Tesis Bisnis (Edisi Revisi). Jakarta: Rajawali Press.

Kotler, Philip. 2005. Manajamen Pemasaran, Jilid 1. Jakarta: PT. Indeks Kelompok Gramedia.

Kotler, Philip dan Gary Armstrong. 2008. Prinsip-prinsip Pemasaran. Edisi 12. Jilid 1. Jakarta: Erlangga.

Kotler, Philip dan Keller, Kevin Lane. 2007. Manajemen Pemasaran, Edisi 13, jilid 1. Jakarta: Airlangga.

Singarimbun. 2010. Metode Penelitian Bisnis. Jakarta: PT Gramedia Pustaka Utama.

Sugiyono. 2012. Metode Penelitian Kuantitatif kualitatif dan R\&D. Bandung: Alfabeta. 